\title{
Table of Contents: The Medicine Forum Volume 21, 2019-2020
}

Follow this and additional works at: https://jdc.jefferson.edu/tmf

Part of the Internal Medicine Commons

Let us know how access to this document benefits you

\section{Recommended Citation}

(2020) "Table of Contents: The Medicine Forum Volume 21, 2019-2020," The Medicine Forum: Vol. 21 , Article 7.

DOI: https://doi.org/10.29046/TMF.021.1.003

Available at: https://jdc.jefferson.edu/tmf/vol21/iss1/7

This Article is brought to you for free and open access by the Jefferson Digital Commons. The Jefferson Digital Commons is a service of Thomas Jefferson University's Center for Teaching and Learning (CTL). The Commons is a showcase for Jefferson books and journals, peer-reviewed scholarly publications, unique historical collections from the University archives, and teaching tools. The Jefferson Digital Commons allows researchers and interested readers anywhere in the world to learn about and keep up to date with Jefferson scholarship. This article has been accepted for inclusion in The Medicine Forum by an authorized administrator of the Jefferson Digital Commons. For more information, please contact: JeffersonDigitalCommons@jefferson.edu. 


\section{TABLE OF CONTENTS}

\section{CLINICAL IMAGES}

BILATERAL INTERCOSTAL LUNG HERNIATIONS: A RARE INCIDENTAL FINDING IN A DYSPNEIC PATIENT

Jillian Cooper, MD, Christine Kurian, MD

\section{CASE REPORTS}

\section{CARDIOLOGY}

AN APPROACH TO REFRACTORY HYPOEXMIA

Daniel Garrido, MD, Evan Nardone, MD, Mark Mallozzi, MD. 7

PERICARDIAL EFFUSION WITH TAMPONADE PHYSIOLOGY IN A PATIENT WITH MULTIPLE MYELOMA

Sairamya Bodempudi MD, Rukaiya Bashir Hamidu MD, Preya Simlote MD, Shuwen Lin MD,

Philip Margiotta MD, Tina Boortalary MD, Gregary D. Marhefka MD

\section{GASTROENTEROLOGY \& HEPATOLOGY}

DIAGNOSING NON-HFE HEREDITARY HEMOCHROMATOSIS

Brian Park, MD, Naman Upadhyay, MD, Dina Halegoua-Demarzio, MD.

\section{HEMATOLOGY \& ONCOLOGY}

AN UNUSUAL TREATMENT FOR CHRONIC MYELOMONOCYTIC LEUKEMIA

Eric Warner, Neil Palmisiano, MD

A CASE REPORT OF HEMOPHAGOCYTIC LYMPHOHISTIOCYTOSIS SECONDARY

TO DISSEMINATED TUBERCULOSIS

Shuwen Lin, MD, Christopher Terry, MD

EXPLORING THE ADVERSE EFFECTS OF CAR-T THERAPY:

A CASE REPORT OF POTENTIAL MINOCA IN CAR-T

Danielle Verghese, MD, Adam Binder, MD, Colin Thomas, MD

A CASE REPORT OF TRAGAXOFUSP CAUSING SEVERE TUMOR LYSIS SYNDROME IN A PATIENT

WITH BLASTIC PLASMACYTOID DENDRITIC CELL NEOPLASM 


\section{INFECTIOUS DISEASE}

A CASE REPORT OF BULLOUS SUBCONJUNCTIVAL HEMORRHAGE IN ADENOVIRAL CONJUNCTIVITIS

Sean Haynie, Jesse Johnson, MD......

PULMONARY MEDICINE

CASE REPORT OF E-CIGARETTE ASSOCIATED LUNG INJURY IN A HEALTHY FEMALE

Mario Fonseca-Paricio, MD, Alan Gandler, MD, Boyd Hehn, MD.

\section{LITERATURE REVIEW}

SERUM AMMONIA AND FOLATE LEVELS: OPPORTUNITIES FOR HIGH VALUE CARE

R. Benson Jones Jr. MD, Sean Dikdan MD, Bracken Babula, MD.

\section{EDITORIAL}

REFUSING TO BE LABELED

Jennifer Perugini. 